\title{
Implementasi Algoritme Support Vector Machines untuk Klasifikasi Area Terbakar di Lahan Gambut
}

\section{(Implementation of Support Vector Machines Algorithm to Classify Burn Area of Peat)}

\author{
Edi Saputra ${ }^{1}$, Ulfa Khaira ${ }^{2}$, Zainil Abidin ${ }^{3}$
}

\begin{abstract}
Forest fires have become annual disasters in Indonesia and have an impact on peatland degradation. Many forest fires occur on peatlands. In August 2019, 810 hotspots were detected in Jambi Province. Burned area of peatland information is needed so that the goverment can determine policy on the effectiveness and efficiency of forest management. Information about burned area of peatland is difficult to obtain from field measurements because the area is large and not easily accessible. Landsat data is a type of image from remote sensing technology that can be used to map this area. One method that is often used to estimate the burned area is visual on-screen interpretation. However, this technique requires experienced interpreters. For this reason, this study used digital interpretation techniques using the Support Vector Machine (SVM) algorithm to classify burned area, vegetation, and bare soil from remote sensed data of protected area of peat in Muaro Jambi District, Jambi Province. This study obtained a classifier with the accuracy of $99.8 \%$. The estimated area of peat based on the SVM classifier on August 15th 2019 are 1,396.89 hectares at the burned area class, 7,069.5 hectares at the vegetation class, and 1,089.54 hectares at the bare soil class.
\end{abstract}

Intisari-Kebakaran hutan telah menjadi bencana tahunan di Indonesia, yang berdampak pada degradasi lahan. Kebakaran hutan banyak terjadi di lahan gambut. Pada bulan Agustus 2019 terdeteksi sebanyak 810 hotspot di Provinsi Jambi. Informasi luas area kebakaran diperlukan untuk menentukan kebijakan dalam pengelolaan hutan dan lahan. Informasi mengenai luas area kebakaran sulit didapatkan dari pengukuran lapangan karena area yang luas dan tidak mudah diakses. Data Landsat merupakan salah satu jenis citra dari teknologi remote sensing yang dapat digunakan untuk memetakan luas area kebakaran. Salah satu metode yang sering digunakan untuk mengestimasi luas area kebakaran adalah dengan teknik interpretasi visual on screen. Namun, teknik ini memerlukan tenaga interpreter yang berpengalaman. Untuk itu, pada makalah ini digunakan teknik interpretasi digital menggunakan algoritme Support Vector Machine (SVM) untuk mengklasifikasikan area kebakaran di Kabupaten Muaro Jambi pada ekosistem gambut indikatif fungsi lindung, kemudian menghitung estimasi luasan lahan vegetasi, lahan terbuka, dan area terbakar. Makalah ini menghasilkan klasifikasi dengan akurasi sebesar $\mathbf{9 9 , 8 \%}$. Estimasi luas gambut berdasarkan klasifikasi SVM pada tanggal 15 Agustus 2019 adalah $1.396,89$ ha teridentifikasi sebagai area

1,2,3 Program Studi Sistem informasi Fakultas Sains dan Teknologi Universitas Jambi, Jl. Jambi - Muara Bulian No.Km. 15, Mendalo Darat, Kec. Jambi Luar Kota, Kabupaten Muaro Jambi Jambi 36122 INDONESIA (email: ${ }^{1}$ edisaputra@unja.ac.id, ${ }^{2}$ ulfa.ilkom@gmail.com, ${ }^{3}$ Zainil.401@gmail.com) terbakar, 7.069,5 ha adalah area vegetasi, dan $1.089,54$ ha merupakan area lahan terbuka.

Kata Kunci-Kebakaran Hutan, Klasifikasi, SVM, Gambut, Remote Sensing.

\section{Pendahuluan}

Kebakaran hutan telah menjadi bencana tahunan di Indonesia dan berdampak pada deforestasi hutan serta kerusakan lingkungan. Forest Watch Indonesia (FWI) melakukan analisis mengenai deforestasi pada periode 20132017. Hasil analisis menunjukkan bahwa dalam rentang waku lima tahun tersebut, sekitar 5,7 juta ha hutan di Indonesia mengalami deforestasi, atau rata-rata sebanyak 1,46 juta ha deforestasi per tahun. Apabila dibandingkan dengan angka rata-rata deforestasi pada periode 2009-2013, yaitu 1,1 juta ha, terlihat bahwa deforestasi pada periode 2013-2017 mengalami peningkatan. Pada tahun 2017, Pulau Kalimatan menjadi pulau yang mengalami deforestasi terluas, yaitu mencapai 528 ribu ha, diikuti oleh Pulau Sumatera dengan luas deforestasi mencapai 251 ha [1].

Kebakaran hutan banyak terjadi di lahan gambut. Pada bulan Agustus 2019 terdeteksi sebanyak 810 hotspot ada di Provinsi Jambi. Kebakaran di lahan gambut dikategorikan sebagai tipe kebakaran yang paling berbahaya dan sangat sulit ditangani dibandingkan dengan kebakaran yang terjadi di kawasan nongambut [2]. Kebakaran gambut (ground fire) sulit dideteksi karena dapat menyebar ke dalam atau menyebar ke lokasi yang lebih jauh tanpa terlihat dari permukaan [3].

Perhitungan luas area terbakar perlu dilakukan untuk mengetahui besar kerugian yang dialami akibat kebakaran lahan. Informasi mengenai deforestasi lahan gambut yang diakibatkan kebakaran lahan berguna bagi pemerintah untuk menentukan kebijakan dalam manajemen hutan [4]. Informasi mengenai luas area kebakaran sulit didapatkan dari pengukuran lapangan karena area yang luas dan tidak mudah diakses. Citra satelit yang dihasilkan dari remote sensing dapat dimanfaatkan untuk menghitung luas area terbakar secara cepat dan murah dibandingkan dengan perhitungan manual di lapangan. Teknologi remote sensing dapat memberikan solusi dalam mengawasi perubahan yang terjadi secara kontinu dan dalam cakupan wilayah yang luas. Salah satu metode yang sering digunakan untuk mengestimasi luas area kebakaran adalah dengan teknik interpretasi visual on screen. Namun, teknik ini memerlukan tenaga interpreter yang berpengalaman [5]. Untuk itu, pada makalah ini digunakan teknik interpretasi digital. 
Teknik interpretasi digital dilakukan dengan memanfaatkan citra satelit melalui proses klasifikasi. Klasifikasi merupakan teknik di bidang data mining yang digunakan untuk membuat model prediksi kelas data pada data yang baru. Berbagai macam algoritme klasifikasi telah diterapkan dalam mengklasifikasi citra satelit. Penelitian mengenai klasifikasi tutupan lahan gambut di Kabupaten Rokan Hilir dengan menerapkan algoritme Support Vector Machine (SVM) berhasil mengklasifikasikan tutupan lahan dengan kelas vegetasi rapat, vegetasi jarang, dan nonvegetasi, dengan akurasi rata-rata 98,2\% [6]. Pada penelitian lainnya, klasifikasi data citra satelit untuk area gambut yang terbakar di Provinsi Riau menerapkan beberapa algoritme pohon keputusan, antara lain algoritme C4.5, algoritme CART, algoritme C5.0, dan algoritme pohon keputusan berbasis autokorelasi spasial. Hasil penelitian yang dilakukan menunjukkan bahwa algoritme C5.0 memiliki akurasi terbaik, yaitu sebesar 99,79\% [7]. Dua penelitian tersebut menggunakan citra satelit Landsat 7 ETM+.

Berdasarkan penelitian sebelumnya, algoritme SVM mampu menghasilkan kinerja yang baik untuk mengklasifikasi kelas vegetasi rapat, vegetasi jarang, dan nonvegetasi, pada citra satelit Landsat 7 ETM+, sehingga makalah ini juga menerapkan algoritme klasifikasi SVM untuk mengklasifikasi kelas area bervegetasi, lahan terbuka, dan terbakar. SVM merupakan algoritme klasifikasi yang dapat bekerja pada data nonlinear. Selain itu, algoritme SVM juga dapat bekerja dengan baik pada data sampel yang terbatas. Data satelit yang digunakan adalah citra satelit Landsat 8 yang memiliki penyempurnaan dari satelit Landsat 7 ETM+ dari sisi jumlah band, rentang spektrum gelombang elektromagnetik terendah yang dapat ditangkap sensor, serta nilai bit (rentang nilai digital number) dari tiap piksel citra. Hasil dari klasifikasi tersebut dapat digunakan untuk menghitung luas area dari masing-masing kelas.

\section{Metodologi}

\section{A. Area Studi dan Data}

Area studi dalam makalah ini adalah Desa Sipin Teluk Duren, Desa Teluk Raya, dan Desa Pemunduran, yang terletak pada area ekosistem gambut indikatif fungsi lindung. Penelitian menggunakan data remote sensing, peta lahan gambut, dan hotspot. Citra Landsat 8 dengan lokasi Kabupaten Muaro Jambi, Provinsi Jambi, didapatkan dari United States Geological Survey (USGS). Data diakuisisi pada tanggal 15 Agustus 2019 dengan resolusi spasial $30 \times 30$ $\mathrm{m}^{2}$. Peta lahan gambut yang digunakan didapatkan dari Kementerian Lingkungan Hidup dan Kehutanan RI. Data hotspot diakuisisi pada bulan Agustus 2019, diperoleh dari MODIS Fire Firms. Data hotspot digunakan untuk menentukan kelas area terbakar.

\section{B. Praproses Citra}

Praproses data dilakukan untuk memperbaiki suatu data sehingga data siap untuk digunakan pada proses selanjutnya. Tahapan praproses yang pertama kali dilakukan adalah koreksi radiometrik yang merupakan proses perbaikan kualitas citra satelit, karena saat pengambilan, pengiriman, serta perekaman data mungkin saja terjadi tidak sempurnanya operasi, posisi matahari, dan sensor. Selanjutnya adalah kombinasi band, dengan mengombinasikan band 7, band 5, dan band 3. Dari proses kombinasi band ini akan dihasilkan citra komposit yang memberikan tampilan optimal untuk identifikasi kebakaran lahan. Band 7 sangat sensitif terhadap pancaran radiasi sehingga dapat mendeteksi sumber panas [8]. Tahap praproses selanjutnya adalah penentuan area studi yang dilakukan dengan cara overlay dan clipping citra satelit dengan peta lahan gambut. Proses overlay dan clipping dilakukan dengan menggunakan perangkat lunak QGIS.

\section{Pelabelan Kelas Area Contoh}

Penentuan label kelas bertujuan untuk memperoleh informasi mengenai kelas-kelas yang akan digunakan dalam klasifikasi. Untuk membuat area contoh dari citra satelit bulan Agustus 2019, digunakan data hotspot bulan Agustus 2019. Data hotspot yang digunakan memiliki nilai confidence lebih dari atau sama dengan 70\%. Para peneliti di bidang kebakaran hutan dan lahan masih menggunakan hotspot sebagai acuan untuk mendeteksi kebakaran hutan dan lahan, tetapi luas kebakaran yang akan terjadi tidak ditentukan oleh banyaknya hotspot [9]. Dalam makalah ini terdapat tiga buah label kelas yang digunakan, yaitu vegetasi, lahan terbuka, dan area terbakar. Penentuan label kelas dilakukan dengan cara overlay data hotspot dengan citra satelit yang digunakan.

\section{Klasifikasi Citra}

Hasil kombinasi band berbentuk citra multispectral tersimpan dalam format .tif, yang terdiri atas tiga layer pada setiap piksel citra, yaitu band 7, 5, dan 3. Ekstraksi nilai reflectance dilakukan dengan menggunakan $\mathrm{R}$ programming dan library RGDAL.

Data dari area contoh citra satelit yang telah diekstraksi dalam nilai digital dibagi menjadi data latih dan data uji. Proses klasifikasi dilakukan dengan menerapkan algoritme SVM setelah kegiatan pembagian data dilakukan.

SVM dikenal sebagai algoritme machine learning yang mampu mengahasilkan kinerja terbaik, meskipun data latih yang dimiliki sedikit [10], [11]. Konsep mendasar dalam klasifikasi SVM ini adalah berusaha mencari hyperplane terbaik dengan margin yang maksimal. Gbr. 1 menunjukkan ilustrasi dari maksimum margin, jarak dari hyperplane ke pattern terdekat masing-masing kelas [12]. Pattern terdekat dari masing-masing kelas ini dikenal sebagai support vector [13].

Kebanyakan data yang digunakan tidaklah linear, sehingga terjadi permasalahan tidak dapat dipisahkan secara linear dalam ruang input. Untuk itu, diperlukan kernel yang dapat mengubah data ke dimensi yang lebih tinggi daripada dimensi aslinya. Pada dimensi ruang yang lebih tinggi ini data dapat dipisahkan secara linear. Kernel linear, polinomial, dan Radial Basis Function (RBF) merupakan beberapa kernel yang sering digunakan dalam SVM. 


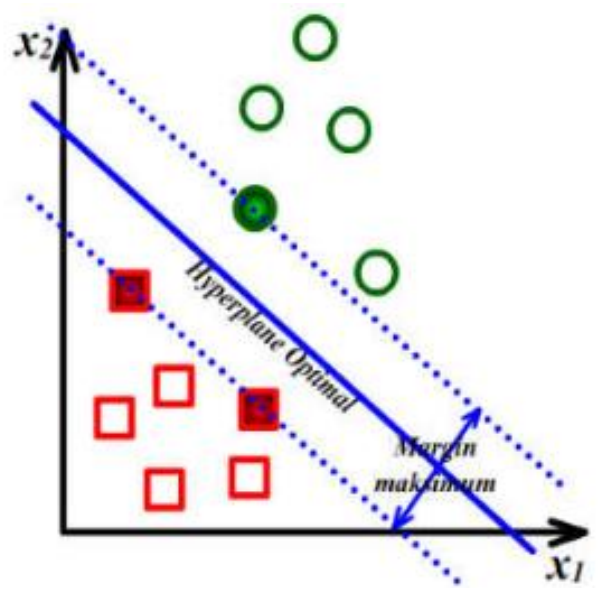

Gbr. 1 Ilustrasi hyperplane.

\section{E. Evaluasi Hasil Klasifikasi}

Untuk merepresentasikan akurasi, dapat digunakan confusion matrix. Confusion matrix dapat digunakan untuk menentukan distribusi kesalahan pada seluruh kelas yang digunakan pada sebuah proses klasifikasi [14]. Nilai akurasi didapatkan dengan cara menghitung jumlah data uji yang terklasifikasi benar dibagi dengan jumlah keseluruhan data uji. Penyajian hasil akurasi dilakukan menggunakan confusion matrix.

Berdasarkan hasil klasifikasi yang dilakukan dengan algoritme SVM, dapat diketahui jumlah piksel dari masingmasing kelas. Jumlah piksel yang diperoleh dari masingmasing kelas dapat digunakan untuk mengestimasi luasan dari lahan gambut pada citra yang digunakan. Estimasi luasan lahan gambut dari masing-masing kelas diperoleh dengan cara mengalikan nilai piksel dengan resolusi spasial citra Landsat 8. Resolusi spasial citra Landsat 8 adalah $30 \times 30 m\left(900 \mathrm{~m}^{2}\right)$.

\section{HASIL DAN PEMBAHASAN}

\section{A. Praproses Citra}

Koreksi radiometrik meliputi kalibrasi radiometrik dan koreksi atmosferik. Koreksi radiometrik dikenal juga dengan istilah koreksi Top of Atmosfer (ToA). Nilai digital number dikonversi ke nilai reflectance [15]. Tahapan koreksi radiometrik dapat dilakukan dengan menggunakan QGIS:Semi Automatic Classification.

Kombinasi band 7 (shortwave infrared 2), band 5 (near infrared), dan band 3 (green) membentuk citra komposit yang dapat digunakan untuk proses klasifikasi tutupan lahan [16]. Kombinasi ini memperlihatkan "natural like". Berdasarkan penampakan pada layar monitor, vegetasi terlihat berwarna hijau gelap, lahan terbuka tampak berwarna cokelat, dan air tampak berwarna biru. Kombinasi ini dapat digunakan pada bidang pertanian, geologi, dan lahan gambut. Jika terdapat lahan yang terbakar, maka lahan tersebut akan tampak berwarna merah. Dari proses kombinasi band ini dihasilkan citra komposit yang memberikan tampilan optimal untuk identifikasi kebakaran lahan (Gbr. 2).

Penentuan AOI digunakan untuk membatasi wilayah penelitian, dilakukan dengan cara overlay dan clipping citra

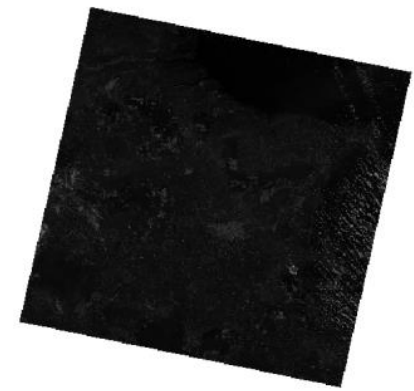

(a)

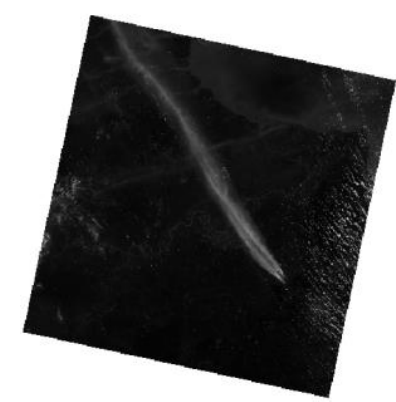

(c)

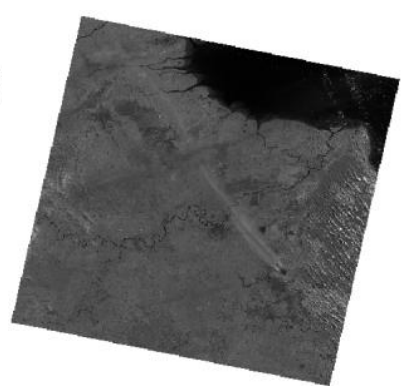

(b)

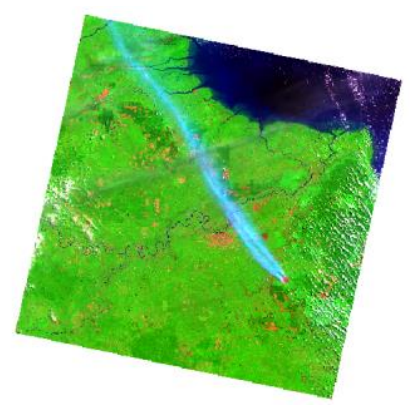

(d)
Gbr. 2 Proses kombinasi band, (a) band 7, (b) band 5, (c) band 3, (d) hasil kombinasi band 7-5-3.

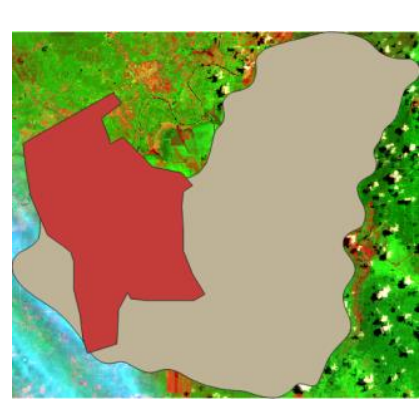

(a)

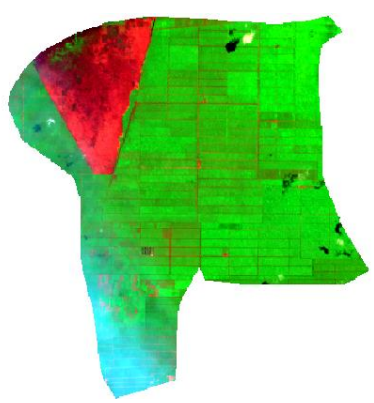

(b)
Gbr. 3 Tahapan penentuan Area of Interest (AOI), (a) proses overlay peta lahan gambut, (b) hasil clipping dengan peta lahan gambut.

raster hasil kombinasi band dengan shapefile peta lahan gambut dan desa yang menjadi objek penelitian. Penelitian ini berfokus pada Desa Sipin Teluk Duren, Desa Teluk Raya, dan Desa Pemunduran, yang terletak pada area ekosistem gambut indikatif fungsi lindung. Proses overlay dan clipping dilakukan menggunakan perangkat lunak QGIS. Gbr. 3 menunjukkan proses pembentukan AOI.

\section{B. Pelabelan Kelas Area Contoh}

Pada makalah ini terdapat tiga buah label kelas yang digunakan, yaitu vegetasi, lahan terbuka, dan area terbakar. Penentuan label kelas dilakukan dengan cara overlay data hotspot dengan citra satelit yang digunakan. Berdasarkan visual citra satelit pada layar monitor (Gbr. 4), warna hijau menandakan kelas vegetasi, warna merah terang dan jika dioverlay terdapat hotspot di atasnya menandakan kelas bekas terbakar, dan warna kecoklatan menandakan kelas lahan terbuka. Area contoh ini digunakan sebagai data latih. 


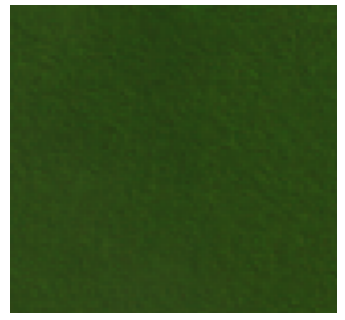

(a)

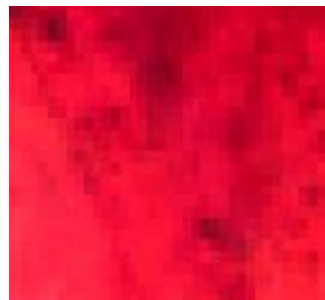

(b)

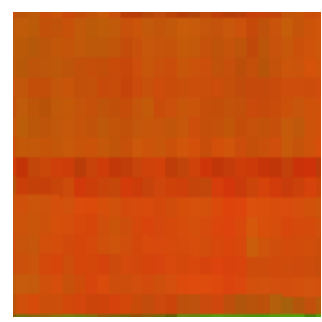

(c)

Gbr. 4 Contoh kelas tutupan lahan, (a) lahan vegetasi, (b) lahan terbakar, (c) lahan terbuka.

\section{Klasifikasi Citra}

Hasil kombinasi band berbentuk citra multispectral dan tersimpan dalam format tif yang terdiri atas tiga layer pada setiap piksel citra, yaitu band 7, 5, dan 3, sehingga perlu dilakukan ekstraksi nilai piksel dari citra, karena proses klasifikasi mengategorikan setiap piksel yang ada dalam sebuah citra satelit ke dalam kelas tutupan lahan tertentu. Pada Gbr. 5 disajikan contoh data hasil ekstraksi nilai piksel dari citra hasil praproses. Hal yang sama juga dilakukan pada data area contoh yang digunakan sebagai data latih (Gbr. 6).

Sebanyak 10\% data dari citra satelit dijadikan area contoh yang dipakai sebagai data latih dan data uji. Metode $K$-fold cross validation digunakan untuk membagi data latih dan data uji. Data dibagi menjadi $K$ kelompok dan percobaan diulang `sebanyak $K$ kali. Data dibagi menjadi sepuluh kelompok percobaan, sebanyak $9 / 10$ data digunakan sebagai data latih dan 1/10 data digunakan sebagai data uji [17]. Dari 10.617 data contoh, sebanyak 9.555 piksel digunakan sebagai data latih, sisanya sebanyak 1.062 digunakan sebagai data uji.

Proses klasifikasi dilakukan dengan menerapkan algoritme SVM setelah kegiatan pembagian data dilakukan. Proses klasifikasi dilakukan dengan menggunakan perangkat lunak $\mathrm{R}$ package e1071. Metode SVM one-versus-one digunakan dalam penelitian ini dan proses pelatihan serta pengujian model SVM diimplementasikan menggunakan perangkat lunak R package e1071.

Berbagai macam fungsi kernel diuji coba, di antaranya RBF dan linear, optimasi parameter $C$ dan $\gamma$ menggunakan metode grid search, parameter $C$ pada rentang $10^{-1}-10^{1}$, dan $\gamma$ pada rentang $10^{-6}-10^{1}$. Tujuan dari metode grid search ini adalah untuk estimasi parameter. Cara kerjanya yaitu dengan membagi jangkauan parameter yang akan dioptimalkan ke dalam grid yang telah ditentukan sebelumnya dan kemudian melintasi semua titik sehingga didapatkan parameter yang optimal [18]. Kerja dari grid search ini dievaluasi dengan cross validation pada data latih. "x", "y", "band7", "band5", "band3"

$378030,-177300,0.0667081326246262,0.427214413881302,0.04246664047241$ $378150,-177030,0.0659536942839622,0.425729840993881,0.04217458143830$ $378000,-177360,0.0656129643321037,0.431254416704178,0.04283171147108$ $378030,-177330,0.0655399635434151,0.429112732410431,0.04271001741290$ $377970,-177360,0.0651505663990974,0.422736376523972,0.04278302565217$ $377940,-177480,0.0642257481813431,0.426849335432053,0.04034925252199$ $378000,-177330,0.064177080988884,0.425097078084946,0.042271938174963$

Gbr. 5 Contoh output hasil ekstraksi dari citra satelit.

\begin{tabular}{|l|}
\hline "x", "y", "band7", "band5", "band3", "class" \\
$378030,-177300,0.066708,0.4272144,0.042466$, vegetasi \\
$378150,-177030,0.065953,0.4257298,0.0421745$, vegetas $i$ \\
$378000,-177360,0.065612,0.4312544,0.0428317$, vegetasi \\
$378030,-177330,0.0655399,0.429112,0.0427100$, vegetas $i$
\end{tabular}

Gbr. 6 Contoh output hasil ekstraksi dari citra satelit untuk data latih vegetasi.

TABEL I

CONFUSION MATRIX KLASIFIKASI CITRA BULAN AgUSTUS TAHUN 2019

\begin{tabular}{|l|c|c|c|}
\hline \multirow{2}{*}{ Kelas Aktual } & \multicolumn{3}{|c|}{ Kelas Prediksi } \\
\cline { 2 - 4 } & Vegetasi & Lahan Terbuka & Terbakar \\
\hline Vegetasi & 5.610 & 7 & 0 \\
\hline Lahan Terbuka & 0 & 2.493 & 7 \\
\hline Terbakar & 0 & 2 & 2.498 \\
\hline
\end{tabular}

Parameter yang optimal merupakan pasangan parameter yang menghasilkan akurasi terbaik dari uji cross validation. Parameter optimal yang didapatkan dari metode grid search digunakan untuk pembentukan model (tahap pelatihan) SVM. Setelah itu, model SVM tersebut digunakan untuk mengklasifikasi data uji. Parameter terbaik untuk hyperplane ditentukan dengan nilai error terkecil. Dari pelatihan diperoleh nilai optimal untuk $C=1$ dan $\gamma=0,1$, sehingga nilai parameter ini akan menjadi masukan dalam pembentukan model SVM.

Pada makalah ini dilakukan percobaan pada dua jenis kernel, yaitu kernel linear dan kernel radial. Dari hasil percobaan didapatkan bahwa baik kernel RBF maupun kernel linear menghasilkan akurasi yang sama, yaitu 99,8\%.

Untuk merepresentasikan akurasi, dapat digunakan confusion matrix. Akurasi keseluruhan merujuk pada jumlah piksel yang terklasifikasi benar pada tiap kelas dibandingkan dengan jumlah sampel yang digunakan untuk uji akurasi [19]. Confusion matrix hasil klasifikasi tutupan lahan gambut bulan Agustus tahun 2019 disajikan pada Tabel I. Akurasi klasifikasi tidak mencapai $100 \%$ karena adanya asap atau awan yang menutupi area gambut yang masih bervegetasi, sehingga ada daerah lain yang tidak terbakar tetapi terdeteksi sebagai area terbakar. Luasan area terbakar dapat dideteksi dengan baik oleh citra Landsat 8 OLI. Namun, citra ini memiliki kelemahan jika terdapat tutupan awan. Jika area terbakar terdapat tutupan awan, metode klasifikasi tidak dapat memproses hasil area terbakar dengan baik.

\section{Estimasi Luas Area Terbakar di Lahan Gambut}

Dari hasil klasifikasi dengan menggunakan algoritme SVM dapat diketahui jumlah piksel dari masing-masing kelas. Visualisasi hasil klasifikasi citra bulan Agustus 2019 disajikan pada Gbr. 7.

Setelah data diklasifikasikan, tahapan selanjutnya adalah menghitung luasan tiap kelas tutupan lahan pada masing- 


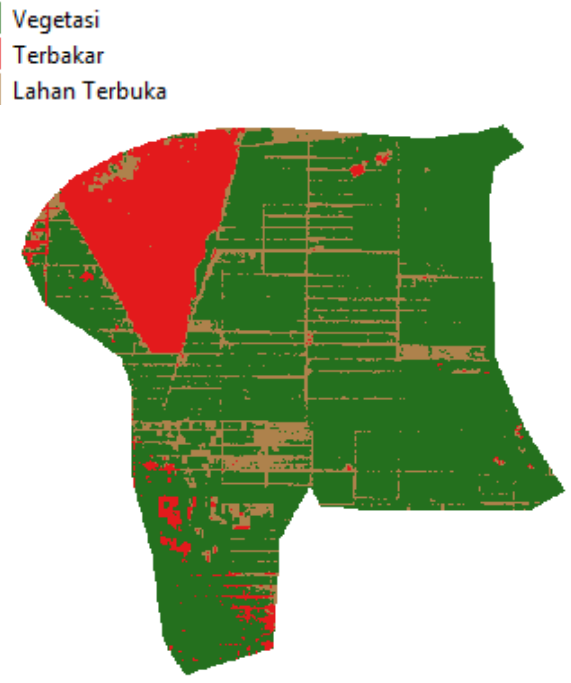

Gbr. 7 Visualisasi hasil klasifikasi.

TABEL II

ESTIMASI LUASAN TUTUPAN LAHAN GAMBUT AGUSTUS TAHUN 2019

\begin{tabular}{|l|c|c|c|}
\hline \multicolumn{1}{|c|}{ Kelas } & $\begin{array}{c}\text { Jumlah } \\
\text { Piksel }\end{array}$ & $\begin{array}{c}\text { Estimasi } \\
\text { Luasan (ha) }\end{array}$ & $\begin{array}{c}\text { Estimasi } \\
\text { Luasan (\%) }\end{array}$ \\
\hline Vegetasi & 78.550 & $7.069,50$ & 73,98 \\
\hline Lahan Terbuka & 12.106 & $1.089,54$ & 11,40 \\
\hline Terbakar & 15.521 & $1.396,89$ & 14,62 \\
\hline
\end{tabular}

masing citra. Untuk mengestimasi luas dari tiap kelas, dapat digunakan jumlah piksel dari tiap kelas. Estimasi luasan tutupan lahan gambut diperoleh dengan cara mengalikan jumlah piksel setiap kelas dengan resolusi spasial Landsat 8 , yaitu sebesar $30 \mathrm{~m} \times 30 \mathrm{~m}\left(900 \mathrm{~m}^{2}\right)$ dan kemudian dikonversi ke hektare. Estimasi luas tutupan lahan gambut disajikan pada Tabel II. Dari Tabel II dapat dilihat bahwa seluas 1.396,9 ha atau $14,62 \%$ wilayah gambut di Muaro Jambi pada bulan Agustus 2019, yang terletak pada area ekosistem gambut indikatif fungsi lindung, terindikasi mengalami kebakaran, seluas $1.089,54$ ha merupakan lahan terbuka, dan 7.069,5 ha wilayah vegetasi.

Untuk melihat hasil klasifikasi tersebut benar area terbakar atau tidak, dilakukan overlay dengan hotspot di bulan Agustus 2019. Hotspot dapat digunakan sebagai alat deteksi kebakaran hutan dan lahan, seperti ditunjukkan pada Gbr. 8. Selain itu, pada makalah ini juga dilakukan cross check dengan peta kebakaran lahan bulan Agustus 2019 yang dirilis oleh Kementerian Lingkungan Hidup dan Kehutanan (KLHK), yaitu dengan melakukan overlay peta kebakaran lahan tahun 2019 dan gambar hasil klasifikasi SVM, seperti pada Gbr. 9.

Poligon dengan garis kuning merupakan wilayah area terbakar dari peta kebakaran lahan, sedangkan area yang berwarna merah merupakan area terbakar hasil klasifikasi SVM. Dari gambar tersebut dapat kita lihat bahwa area terbakar hasil klasifikasi dengan SVM benar berada pada area terbakar. Luas area terbakar pada wilayah tersebut berdasarkan peta kebakaran lahan tahun 2019 adalah seluas 1.263,26 ha, sementara hasil yang didapat dari hasil penelitian ini adalah seluas 1.396,89 ha. Perbedaan ini disebabkan pada citra Landsat 8 OLI yang digunakan terdapat asap atau awan

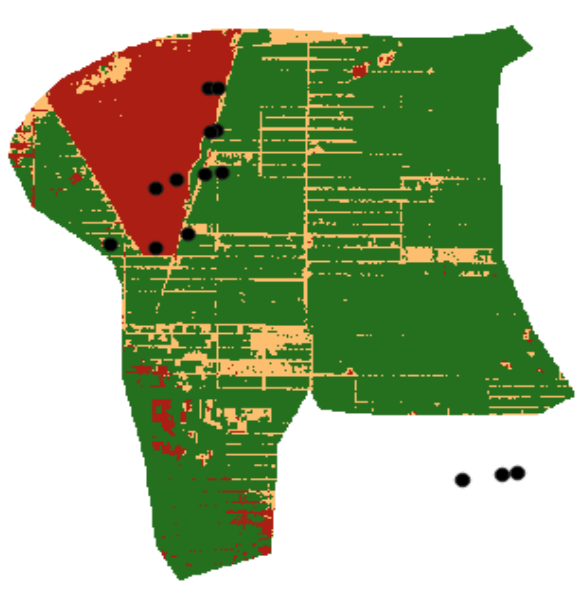

Gbr. 8 Overlay hotspot dengan hasil klasifikasi.

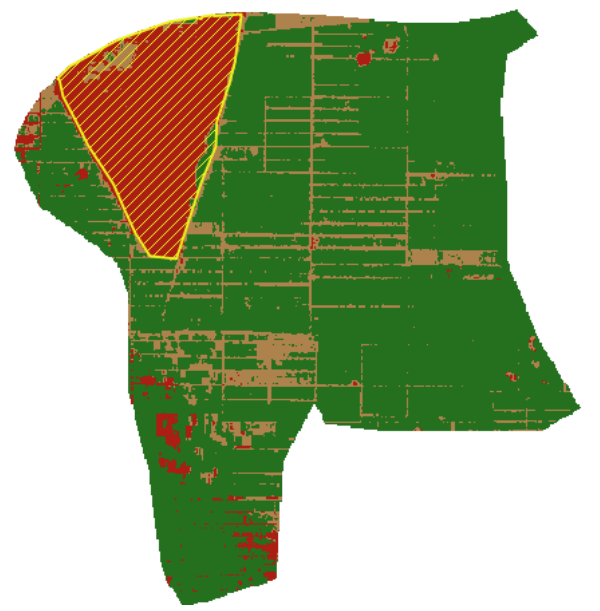

Gbr. 9 Perbandingan area terbakar hasil klasifikasi dengan peta kebakaran dari KLHK.

yang menutupi area gambut yang masih bervegetasi, sehingga ada daerah lain yang tidak terbakar tetapi terdeteksi sebagai area terbakar.

\section{KESIMPULAN}

Makalah ini melakukan estimasi luas area gambut yang terbakar pada area ekosistem gambut indikatif fungsi lindung di Kumpeh Ulu kabupaten Muaro Jambi, Provinsi Jambi, pada bulan Agustus 2019. Algoritme SVM diimplementasi untuk mengklasifikasikan area lahan gambut berbasis citra satelit, kemudian menghitung estimasi luasan lahan vegetasi, lahan terbuka, dan area terbakar. Algoritme SVM menghasilkan akurasi terbaik, yaitu sebesar 99,8\%. Pada bulan Agustus 2019, seluas 1.396,89 ha wilayah gambut di Kumpeh Ulu Muaro Jambi teridentifikasi mengalami kebakaran, seluas $1.089,54$ ha merupakan lahan terbuka, dan 7.069,5 ha wilayah vegetasi.

\section{UCAPAN TERIMA KASIH}

Kegiatan penelitian ini mendapat bantuan dana PNBP Lembaga Penelitian dan Pengabdian Kepada Masyarakat Skema Penelitian Dasar Unggulan Universitas Nomor: 023.17.2.677565/2020 tanggal 27 Desember 2019 dan Surat 
Perjanjian Penugasan Dalam Rangka Pelaksanaan Penelitian Nomor: 434/UN21.18/PG/SPK/2020 tanggal 20 April 2020. Terima kasih disampaikan kepada Kementerian Lingkungan Hidup dan Kehutanan (KLHK) dan Badan Restorasi Gambut atas bantuan sumber data yang diberikan, sehingga penelitian terlaksana dengan baik dan lancar.

\section{REFERENSI}

[1] (2019) “Angka Deforestasi Sebagai 'Alarm' Memburuknya Hutan, [Online], https://fwi.or.id/wp-content/uploads/2019/10/FS_Deforestasi _FWI_small.pdf, tanggal akses: 15-Sep-2020.

[2] L. Syaufina, "Forest and Land Fires in Indonesia: Assessment and Mitigation," dalam Integrating Disaster Science and Management, P. Samui, D. Kim, dan C. Ghosh, Eds., Amsterdam, Netherlands: Elsevier, 2018, hal. 109-121.

[3] W.C. Adinugroho, I.N.N. Suryadiputra, B.H. Saharjo, dan L. Siboro, Panduan Pengendalian Kebakaran Hutan dan Lahan Gambut. Bogor, Indonesia: Wetlands International - Indonesia Programme dan Wildlife Habitat Canada, 2005.

[4] Suwarsono, Rokhmatuloh., dan T. Waryono, "Pengembangan model identifikasi daerah bekas kebakaran hutan dan lahan (burned area) menggunakan citra MODIS di Kalimantan," J. Penginderaan Jauh dan Pengolahan Data Citra Digital, Vol. 10, No. 2, hal. 93-112, 2013.

[5] D. Kosasih, M.B. Saleh, dan L.B. Prasetyo, "Visual and Digital Interpretations for Land Cover Classification in Kuningan District, West Java,” J. Ilmu Pertan. Indones., Vol. 24, No. 2, hal. 101-108, 2019.

[6] U. Khaira, I.S. Sitanggang, dan L. Syaufina, "Detection and Prediction of Peatland Cover Changes Using Support Vector Machine and Markov Chain Model," TELKOMNIKA (Telecommunication Comput. Electron. Control), Vol. 14, No. 1, hal. 294-301, 2016.

[7] P. Thariqa, I.S. Sitanggang, dan L. Syaufina, "Comparative Analysis of Spatial Decision Tree Algorithms for Burned Area of Peatland in Rokan Hilir Riau," TELKOMNIKA (Telecommunication Comput. Electron. Control), Vol. 14, No.2, hal. 684-691, 2016.

[8] C. Pennington, "Burn Scar Mapping in the Sabine National Wildlife Refuge Using Landsat TM and ETM+ Imagery," Thesis, Louisiana State University, Baton Rouge, USA, 2006.

[9] I. Prasasti, R. Boer, M. Ardiansyah, A. Buono, dan L. Syaufina, "Analisis Hubungan Kode-Kode SPBK (Sistem Peringkat Bahaya Kebakaran) dan Hotspot dengan Kebakaran Hutan dan Lahan di
Kalimantan Tengah," J. Nat. Resour. Environ. Manag., Vol. 2, No. 2, hal. 91-101, 2012.

[10] C. Huang, L.S. Davis, dan J.R.G. Townshend, "An Assessment of Support Vector Machines for Land Cover Classification," Int. J. Remote Sens., Vol. 23, No. 4, hal. 725-749, 2002.

[11] A.T. Azar dan S.A. El-Said, "Performance Analysis of Support Vector Machines Classifiers in Breast Cancer Mammography Recognition," Neural Comput. Appl., Vol. 24, No. 5, hal. 1163-1177, 2014.

[12] C. Pitoy, "Metode Support Vector Machines pada Klasterisasi K-Means Data Nonlinear Separable," Frontiers: Jurnal Sains Dan Teknologi., Vol. 2, No. 1, hal. 71-77, 2010.

[13] J. Weston, S. Mukherjee, O. Chapelle, M. Pontil, T. Poggio, dan V Vapnik, "Feature Selection for SVMs," Proc. Advances in Neural Information Processing Systems, 2001, hal. 668-674.

[14] L.I. Kuncheva, Combining Pattern Classifiers. Hoboken, USA: John Wiley \& Sons, Inc., 2014.

[15] M.Z. Lubis, H.M. Taki, W. Anurogo, D.S. Pamungkas, P. Wicaksono, dan T. Aprilliyanti, "Mapping the Distribution of Potential Land Drought in Batam Island Using the Integration of Remote Sensing and Geographic Information Systems (GIS)," IOP Conference Series: Earth and Environmental Science, Vol. 98, The 5th Geoinformation Science Symposium, 2017, hal. 1-8.

[16] L.S. Wijedasa, S. Sloan, D.G. Michelakis, dan G.R. Clements, "Overcoming Limitations with Landsat Imagery for Mapping of Peat Swamp Forests in Sundaland," Remote Sens., Vol. 4, No. 9, hal. 25952618, 2012.

[17] I.H. Witten, E. Frank, M.A. Hall, dan C.J. Pal, Data Mining: Practical Machine Learning Tools and Techniques, Burlington, USA: Morgan Kaufmann, 2011.

[18] P. Lameski, E. Zdravevski, R. Mingov, dan A. Kulakov, "SVM Parameter Tuning with Grid Search and Its Impact on Reduction of Model Over-fitting," dalam Rough Sets, Fuzzy Sets, Data Mining, and Granular Computing. Lecture Notes in Computer Science, Vol. 9437, Y. Yao, Q. Hu, H. Yu, J.W. Grzymala-Busse, Eds., Cham, Switzerland: Springer, 2015, hal. 464-474.

[19] F. Yuan, K.E. Sawaya, B.C. Loeffelholz, dan M.E. Bauer, "Land Cover Classification and Change Analysis of the Twin Cities (Minnesota) Metropolitan Area by Multitemporal Landsat Remote Sensing," Remote Sens. Environ., Vol. 98, No. 2, hal. 317-328, Okt. 2005. 